\title{
Educate cadres for the prevention of Covid-19 in Sei Mati Village, Medan Maimun District
}

\author{
Rahayu Lubis ${ }^{1 *}{ }^{*}$ Jemadi $^{1}$, Rasmaliah $^{1}$ \\ ${ }^{1}$ Departemen Epidemiologi, Fakultas Kesehatan Masyarakat Universitas Sumatera Utara \\ *Email: rahayu@usu.ac.id
}

\begin{abstract}
The first case of Covid-19 in Indonesia was in early March 2020 and continues to grow until December 13, 2020, reaching 617820 positive for Covid-19 and 18,819 deaths. Data in North Sumatra Province, there are 16,682 positive Covid-19 and 640 deaths and Medan City statistical data there are 8192 people positive for Covid-19 and 327 died. Prevention of Covid-19 transmission needs to be done by involving cadres, therefore this service aims to form health cadres and provide educational packages on the prevention of Covid-19 transmission in Sei Mati Village, Medan Maimun District. The reason for choosing the location was because cadres played an active role in their environment. Participants are health cadres such as posyandu cadres. The method used to measure knowledge using a questionnaire before and after the intervention (pre and post test design). The intervention was in the form of lectures and questions and answers using in-focus followed by videos. The implementation of community service was carried out in the Sei Mati village head office hall on September 26, 2020. Participants who attended were 25 people with an average age of 36 years. There was an increase in knowledge and efforts to prevent Covid-19 by $14.7 \%$ after intervention. Regular outreach efforts to the community are needed about efforts to increase immunity and maintain health protocols and the availability of running water for washing hands to avoid Covid-19 transmission. The output of this service is in the form of journal articles, educational videos and newspaper publications.
\end{abstract}

Keyword: Covid-19, education, cadre, Corona virus, prevention

\begin{abstract}
Abstrak
Kasus pertama Covid-19 di Indonesia pada awal Maret 2020 dan terus bertambah sampai tanggal 13 Desember 2020 mencapai 617820 positif Covid-19 dan 18.819 meninggal. Data di Propinsi Sumatera Utara ada 16.682 positif Covid-19 dan 640 meninggal dan data statistik Kota Medan ada 8192 orang positif Covid-19 dan 327 meninggal. Pencegahan penularan Covid-19 perlu dilakukan dengan melibatkan kader, oleh karena itu pengabdian ini bertujuan untuk membentuk kader kesehatan dan pemberian paket edukasi tentang pencegahan penularan Covid-19 di Kelurahan Sei Mati Kecamatan Medan Maimun. Alasan pemilihan lokasi karena kader berperan aktif di lingkungannya. Peserta adalah kader kesehatan seperti kader posyandu. Metode yang digunakan pengukuran pengetahuan menggunakan kuesioner sebelum dan sesudah intervensi (pre and post test design). Intervensi berupa ceramah dan tanya jawab memakai in focus dilanjutkan dengan video. Pelaksanaan pengabdian pada masyarakat dilakukan di aula kantor lurah Sei Mati tanggal 26 September 2020. Peserta yang hadir sebanyak 25 orang umur rata-rata 36 tahun. Terdapat peningkatan pengetahuan dan upaya pencegahan Covid-19 sebesar 14,7\% setelah di intervensi. Perlu upaya penyuluhan yang rutin pada masyarakat tentang upaya meningkatkan imunitas dan menjaga protokol kesehatan dan ketersediaan air mengalir untuk mencuci tangan agar terhindar dari penularan Covid-19. Luaran pengabdian berupa artikel jurnal, video edukasi dan publikasi koran
\end{abstract}

Kata Kunci: Covid-19, edukasi, kader, Corona virus, pencegahan 


\section{PENDAhUluan}

Corona Virus Disease (Covid-19) merupakan penyakit baru yang menyerang seluruh dunia. Penyakit ini disebabkabn virus corona disebut dengan Severe Acute Respiratory Syndrome Corona virus type 2 (SARS CoV-2) (Gorbalenya et al., 2020). Kasus pertama terjadi di Kota Wuhan China pada Desember 2019 dan sekarang WHO telah menetapkan Covid-19 sebagai pandemi di dunia. Sejak tanggal 2 Maret 2020 kasus pertama Covid-19 terjadi di Indonesia, dan terus bertambah setiap harinya sehingga mencapai 629.429 kasus konfirmasi per tanggal 15 Desember 2020 dengan jumlah kematian 19.111 orang (3,04\%) (Satgas Covid-19, 2020). Kejadian Covid-19 di Propinsi Sumatera Utara ada 16.843 kasus konfirmasi dengan kematian sebanyak 645 orang (3,83\%) (Posko Covid-19 Provsu, 2020). Data statistik harian kota Medan pada tanggal yang sama menunjukkan ada 8.153 kasus konfirmasi positif Covid-19 dan meninggal 327 orang (4,01\%) (Posko Covid-19 Kota Medan,2020).

Covid-19 merupakan salah satu penyakit dengan kemampuan menularkan yang sangat cepat (superspreader). Masa inkubasi covid-19 (masa inkubasi adalah waktu yang diperlukan dari mulai masuknya virus SARS CoV-2 sampai timbul gejala) sekitar 2-14 hari maksudnya jika dalam rentang waktu tersebut virus masuk ke tubuh manusia maka akan timbul gejala gejala seperti flu yaitu batuk, pilek, demam, sakit kepala, sesak napas ringan sampai berat dan bisa terjadi diare. Ada tiga faktor yang mempengaruhi terjadinya penyakit yang disebut dengan "segitiga epidemiologi" yaitu faktor agent (penyebab penyakit), faktor host/inang (manusia atau hewan) dan environtment (lingkungan). Bila ketiga faktor ini dijaga dalam keadaan seimbang maka orang akan tetap sehat, bila salah satu faktor tidak ada maka penyakit tidak akan muncul (Lin et al., 2020)

Faktor agent. Covid-19 adalah penyakit zoonosis (penyakit yang ditularkan dari hewan ke manusia). Hewan penularnya kelelawar, treggiling, ular, babi, dll. Agent penyebab Covid-19 adalah virus SARS CoV-2 yaitu virus yang kuat virulensinya, menyukai saluran napas sebagai tempat berkembang biak. Virus berantai tunggal, berbentuk seperti bola, di kelilingi seperti duri, mempunyai lapisan luar terbuat dari lemak yang mudah hancur dengan sabun/desinfektan. Virus ini tidak tahan hidup di udara luar dan sinar matahari oleh karena itu memerlukan inang (host) untuk dapat hidup, inangnya bisa manusia atau hewan, tetapi virus ini lebih ganas pada manusia dibandingkan pada hewan. Virus ini suka pada suhu dingin seperti ruangan ber-AC tapi mati pada suhu diatas 65 derajat celcius.

Faktor host. Host utama dari virus corona adalah hewan tetapi pada akhir tahun 2019 di Wuhan terjadi penularan dari manusia ke manusia. Faktor intrinsik individu dapat mempengaruhi paparan, kerentanan atau respon terhadap agen penyebab. Peluang untuk terjadinya paparan di pengaruhi oleh kontak antar manusia. Kerentanan di pengaruhi oleh imunitas tubuh, status gizi, adanya penyakit lain (co-morbid), konsumsi obat obatan dan faktor psikologis

Faktor environment. Lingkungan mengacu pada faktor ektrinsik yang mempengaruhi agen dan peluang untuk terpapar. Faktor lingkungan fisik termasuk iklim dan geologi misalnya slum area (kumuh) akan mempermudah penularan virus karena banyak kontak antar manusia. Lingkungan sosial budaya misalnya adanya acara yang mengumpulkan banyak orang (crowded), sanitasi lingkungan dan ketersediaan fasilitas kesehatan merupakan faktor yang mempengaruhi penularan Covid-19.

Upaya-upaya pencegahan Covid-19. Penularan virus Corona terjadi antar manusia bisa melalui percikan ludah (droplet) dari orang yang terinfeksi Covid-19 bila bersin, batuk atau berbicara, jarak tular droplet sekiar 1-1,8 meter, bisa juga lewat kontak langsung seperti berjabat tangan atau kita menyentuh benda-benda lain seperti handle pintu, pegangan tangga, yang sudah terkontaminasi virus lalu tangan kita menyentuh mulut, hidung atau mata sehingga virus tersebut dapat masuk ke tubuh kita.

Peran manusia paling utama untuk memutus rantai penularan Covid-19 seperti menjaga kebersihan diri dan lingkungannya, sering mencuci tangan pakai sabun, menghindari keramaian (physical distancing), menggunakan masker, tidak menyentuh area wajah sembarangan, peralatan makan terpisah dan menjaga imunitas tubuh tetap tinggi (dengan makan gizi seimbang, konsumsi 
sayur dan buah yang mengandung vitamin $\mathrm{C}$, berolah raga, berjemur dan cukup beristirahat). Strategi yang dapat dilakukan untuk memantau keseimbangan host adalah dengan memantau status demam harian warga dengan menggunakan thermal scan atau survei demam dilingkungan RT/RW, bekerja dari rumah, memantau pergerakan warga, melakukan deteksi dini dan membantu proses rujukan (Kemkes RI, 2020)

Menyeimbangkan virus corona merupakan hal yang sulit karena sampai saat ini vaksinnya belum ditemukan dan masih dalam penelitian. Lingkungan yang bersih dan tidak banyak kerumunan orang perlu dijaga untuk pencegahan penularan covid-19. Pemerintah sudah mengeluarkan berbagai peraturan untuk mengatur pergerakan orang dan pembatasan untuk mencegah terjadinya kerumunan orang. kendati pun sudah dilakukan kebijakan seperti itu masih ada saja yang melanggar dan tidak melakukan physical distancing dengan baik, hal ini membuat terus meningkatnya kasus COVID-19 di Indonesia

Kecamatan Medan Maimun terletak di tengah Kota Medan, terdiri dari 6 Kelurahan yaitu Kelurahan Aur, Hamdan, Jati, Kampung Baru, Sukaraja dan sei Mati. Di Kelurahan Sei Mati ada 4 orang dalam pemantauan (ODP) Covid-19 dan 1 orang pelaku perjalanan (PP) tapi belum mempunyai orang dalam pengawasan (ODP) Covid-19 sedangkan Kelurahan lainnya sudah ada ODP. Oleh karena itu perlu upaya tindakan pencegahan sedini mungkin agar Covid-19 tidak terjadi di daerah ini. Upaya pencegahan penularan Covid-19 dilakukan dengan cara pembentukan dan pelatihan kader kesehatan tentang Covid-19 dan mampu mendeteksi faktor risiko covid-19 sedini mungkin dan memantau gejala klinis yang terjadi seperti survei demam di lingkungannya. Oleh karena alasan tersebut diatas maka perlu dibuat suatu pengabdian untuk pembentukan kader kesehatan dan paket edukasi untuk pencegahan penularan Covid-19 di Kelurahan Sei Mati Kecamatan Medan Maimun yang bertujuan peningkatan pengetahuan masyarakat tentang penularan Covid-19 dan cara penanggulangannya untuk mencegah Covid-19 tidak terjadi. Untuk membentuk kader kesehatan dan peningkatan pengetahuan tentang Covid-19 dengan paket edukasi cara pencegahan penularan Covid-19 sehingga kader tersebut dapat menyebarluaskan pengetahuannya kepada masyarakat lainnya untuk dapat mencegah terjadinya Covid-19 di Kelurahan Sei Mati.

\section{METODE PELAKSANAAN}

Tujuan pengabdian ini adalah untuk membentuk kader kesehatan guna mencegah penularan Covid19 di Kelurahan Sei Mati Kecamatan Medan Maimun. Kecamatan Medan Maimun berbatasan dengan Kecamatan Medan Kota yang sudah merupakan zona merah Covid-19. Zona merah maksudnya daerah yang sudah mempunyai PDP lebih dari 10 orang, ada kejadian Covid-19 dan ada yang meninggal. Kegiatan pengabdian ini dilakukan di Kelurahan Sei Mati Kecamatan Medan Maimun Alasan pemilihan lokasi ini karena Kelurahan Sei Mati masih kategori zona Kuning maksudnya PDP masig dibawah 10 orang. Masyarakat di Kelurahan Sei Mati partisipatif dan mau berperan aktif terhadap kegiatan-kegiatan yang baik untuk lingkungannya. Kelompok sasaran adalah kader kesehatan seperti kader posyandu yang sudah terbiasa dikenal oleh masyarakat dilingkungannya. Kegiatan pengabdian berupa pelatihan kader dengan pemberin paket edukasi tentang Covid-19 mulai dari pengenalan sifat-sifat virus corona, cara penularan, faktor pendukung dan cara pencegahan penularan Covid-19. Setelah diberi pelatihan akan diadakan pengukuran pengetahun sebelum dan sesudah pelatihan atau disebut juga pre and post test design pada satu kelompok. Kuesioner yang sudah distandarisasi diberikan kepada kader sebelum di latih. Jenis penyuluhan yang diberikan kepada kader adalah metode ceramah dan tanya jawab. Kegiatan ceramah memakai alat bantu in focus sehingga pemutaran video tentang cara penularan Covid-19 dan gejala klinisnya. Materi pelatihan tentang pengenalan virus corona, bagaimana cara penularan, gejala klinis, pemeriksaan laboratorium, dan bagaimana cara pencegahan penularan Covid-19. Setelah pelatihan dilakukan terhadap kader, kuesioner yang sama diberikan kembali kepada kader untuk dievaluasi hasilnya apakah ada peningkatan pengetahuan tentang Covid-19 dan seberapa besar peningkatan tersebut 
Partisipasi mitra yaitu lurah Sei mati Kecamatan Medan Maimun terhadap pelaksanaaan pengabdian masyarakat sangat mendukung, bahkan mengizinkan aula kelurahan untuk digunakan sebagai tempat pelaksanaan kegiatan pelatihan kader kesehatan dalam upaya peningkatan pengetahuan kader agar dapat mencegah terjadinya penularan Covid-19 sedini mungkin.

\section{HASIL DAN PEMBAHASAN}

\subsection{Karakteristik Peserta Pengabdian}

Pengabdian kepada masyarakat dilaksanakan pada hari Sabtu tanggal 26 September 2020, bertempat di aula Kantor lurah Sei Mati Kecamatan Medan Maimun. Jumlah peserta pengabdian yang hadir 25 orang terdiri dari 18 orang $(72 \%)$ perempuan dan 7 orang (28\%) laki-laki. Peserta pengabdian rata rata berumur 36 tahun, umur tertinggi 65 tahun dan terendah 16 tahun. Status perkawinan peserta pengabdian di kategorikan dengan status kawin ada 16 orang (64\%) dan belum kawin ada 9 orang (36\%). Sekitar 19 orang (76\%) dengan pendidikan SLTA/sederajat dan sebagian besar peserta pengabdian yaitu 13 orang (52\%) bekerja di sektor swasta, yang bekerja sebagai ibu rumah tangga ada 9 orang (36\%). Semua keterangan diatas dapat dilihat pada Tabel 3.1 dibawah ini:

\begin{tabular}{|c|c|c|c|c|c|}
\hline No & $\begin{array}{l}\text { Umur } \\
\text { (Tahun) }\end{array}$ & Jenis Kelamin & $\begin{array}{l}\text { Status } \\
\text { perkawinan }\end{array}$ & Pendidikan & Pekerjaan \\
\hline 1 & 43 & Perempuan & Kawin & SMA & IRT \\
\hline 2 & 48 & Perempuan & Kawin & S1 & Karyawan Swasta \\
\hline 3 & 40 & Perempuan & Kawin & SMK & IRT \\
\hline 4 & 37 & Perempuan & Kawin & SMA & IRT \\
\hline 5 & 36 & Laki-laki & Kawin & S1 & Karyawan Swasta \\
\hline 6 & 26 & Perempuan & Belum Kawin & SMA & Berdagang \\
\hline 7 & 41 & Perempuan & Kawin & D1 & IRT \\
\hline 8 & 35 & Perempuan & Kawin & SMA & IRT \\
\hline 9 & 53 & Perempuan & Kawin & SMA & IRT \\
\hline 10 & 65 & Perempuan & Janda & SMA & IRT \\
\hline 11 & 22 & Perempuan & Kawin & SMA & IRT \\
\hline 12 & 27 & Perempuan & Kawin & SMK & IRT \\
\hline 13 & 47 & Laki-laki & Kawin & SMA & Karyawan Swasta \\
\hline 14 & 60 & Perempuan & Belum Kawin & D3 & Wiraswasta \\
\hline 15 & 48 & Perempuan & Kawin & SMA & IRT \\
\hline 16 & 53 & Perempuan & Kawin & SMA & Wiraswasta \\
\hline 17 & 30 & Laki-laki & Kawin & SMA & Karyawan Swasta \\
\hline 18 & 46 & Perempuan & Kawin & SMK & Guru PAUD \\
\hline 19 & 22 & Laki-laki & Belum Kawin & SMA & Karyawan Swasta \\
\hline 20 & 21 & Laki-laki & Belum Kawin & SMK & Karyawan Swasta \\
\hline 21 & 25 & Perempuan & Belum Kawin & S1 & Wiraswasta \\
\hline 22 & 23 & Perempuan & Belum Kawin & SMA & Wiraswasta \\
\hline 23 & 18 & Laki-laki & Belum Kawin & SMA & Mahasiswa \\
\hline 24 & 16 & Laki-laki & Belum Kawin & SMA & Pelajar \\
\hline 25 & 20 & Perempuan & Belum Kawin & SMA & Mahasiswa \\
\hline
\end{tabular}

Tabel 3.1. Karakteristik peserta pengabdian kepada masyarakat 


\subsection{Pengetahuan dan Upaya pencegahan Covid-19}

Peserta pengabdian diberikan kuesioner berisi pertanyaan-pertanyaan tentang pengetahuan dan upaya pencegahan Covid-19 sebelum dan sesudah intervensi ceramah dan tanya jawab dilakukan. Nilai rata-rata dari jawaban pertanyaan kuesioner pada peserta pengabdian sebelum dilakukan intervensi ceramah dan tanya jawab adalah 7,9 (SD 2,9). Sedangkan nilai rata-rata jawaban pertanyaan kuesioner setelah intervensi ceramah dan tanya jawab dilakukan adalah 10,9 (SD 2,9). Nilai maksimun bila peserta pengabdian dapat menjawab semua pertanyaan adalah 15 , sebelum intervensi nilai rata rata yang didapat adalah $7,9(52 \%)$, setelah intervensi nilai rata rata yang didapat adalah 10,9 (66,7\%), dari hasil tersebut maka dapat dilihat ada peningkatan nilai rata rata peserta pengabdian tentang pengetahuan dan upaya pencegahan Covid-19 sebelum dan sesudah intervensi sebesar $14,7 \%$.

Dari jawaban daftar pertanyaan sebelum dilakukan intervensi dapat diketahui masih rendahnya pengetahuan peserta pengabdian tentang jarak tular virus corona bila seseorang yang terinfeksi Covid-19 batuk, lama pemakaian masker dan kapan harus ganti masker, cara mencuci tangan yang benar dan stigmatisasi pada penderita Covid-19. Setelah intervensi ceramah dan tanya jawab dilakukan dapat dilihat terjadi peningkatan pengetahuan tentang Covid-19 dan upaya pencegahannya, walaupun masih ada yang pengetahuan tentang cara penularan Covid-19 dan manfaat minuman panas yang hasil jawabannya sama sebelum dan sesudah intervensi. Upaya untuk meningkatkan imunitas tubuh perlu untuk lebih diberikan intervensi berkelanjutan karena dalam hal ini peningkatan nilai sebelum dan sesudah intervensi hanya sekitar $2 \%$. Hal-hal tersebut diatas dapat dilihat pada Tabel 3.2 dibawah ini:

\begin{tabular}{|c|c|c|c|c|c|}
\hline \multirow[t]{2}{*}{ No } & \multirow{2}{*}{ Daftar Pertanyaan } & \multicolumn{2}{|c|}{ Pre- test } & \multicolumn{2}{|c|}{ Post-test } \\
\hline & & Benar & Salah & Benar & Salah \\
\hline 1 & Penyebab Covid-19 & $19(76 \%)$ & $6(24 \%)$ & $22(88 \%)$ & $3(12 \%)$ \\
\hline 2 & Cara penularan Covid-19 & $17(68 \%)$ & $8(32 \%)$ & $17(68 \%)$ & $8(32 \%)$ \\
\hline 3 & Jarak tular virus Corona & $3(12 \%)$ & $22(88 \%)$ & $15(60 \%)$ & $10(40 \%)$ \\
\hline 4 & Etika batuk & $12(48 \%)$ & $13(52 \%)$ & $19(76 \%)$ & $6(24 \%)$ \\
\hline 5 & Upaya pencegahan Covid-19 & $19(76 \%)$ & $6(24 \%)$ & $23(92 \%)$ & $2(8 \%)$ \\
\hline 6 & Manfaat minuman panas & $11(44 \%)$ & $14(56 \%)$ & $11(44 \%)$ & $14(56 \%)$ \\
\hline 7 & Pemakaian masker & $9(36 \%)$ & $16(64 \%)$ & $18(72 \%)$ & $7(28 \%)$ \\
\hline 8 & Lama waktu masker harus diganti & $21(84 \%)$ & $4(16 \%)$ & $23(92 \%)$ & $2(8 \%)$ \\
\hline 9 & Pentingnya asupan Vitamin C & $16(64 \%)$ & $9(36 \%)$ & $23(92 \%)$ & $2(8 \%)$ \\
\hline 10 & Gejala klinis Covid-19 & $14(56 \%)$ & $11(44 \%)$ & $20(80 \%)$ & $5(20 \%)$ \\
\hline 11 & Cara mencuci tangan yang benar & $10(40 \%)$ & $15(60 \%)$ & $18(72 \%)$ & $7(28 \%)$ \\
\hline 12 & Meningkatkan imunitas tubuh & $13(52 \%)$ & $12(48 \%)$ & $14(56 \%)$ & $11(44 \%)$ \\
\hline 13 & Obat herbal/tradisional & $14(56 \%)$ & $11(44 \%)$ & $18(72 \%)$ & $7(28 \%)$ \\
\hline 14 & Protokol Covid-19 pada jenazah & $15(60 \%)$ & $10(40 \%)$ & $23(92 \%)$ & $2(8 \%)$ \\
\hline 15 & Stigma Covid-19 & $8(32 \%)$ & $17(68 \%)$ & $12(48 \%)$ & $12(48 \%)$ \\
\hline
\end{tabular}

Tabel 3.2. Hasil pengukuran kuesioner sebelum dan sesudah intervensi 


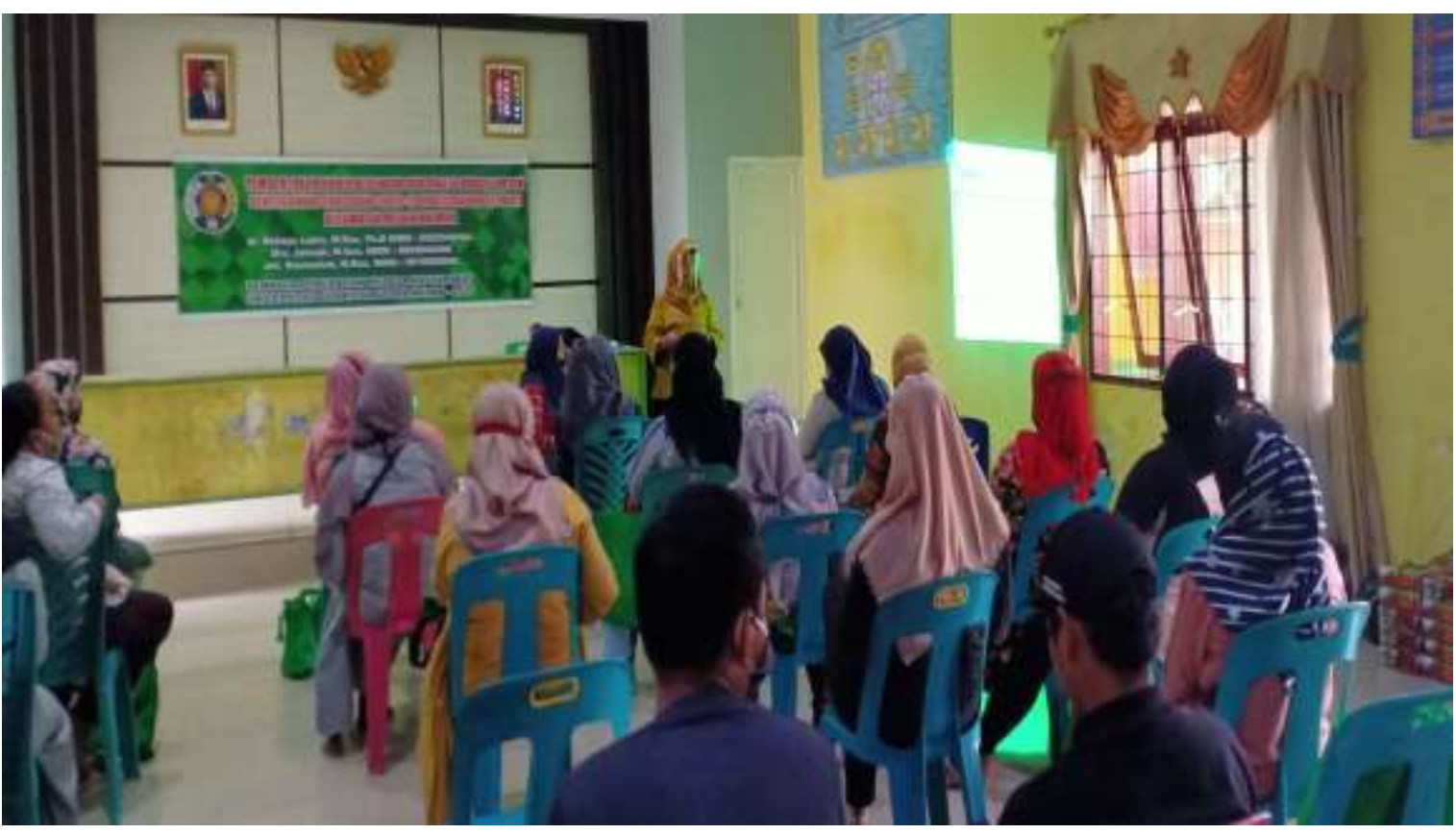

Gambar 3.1 Pemberian intervensi edukasi kader tentang pencegahan Covid-19

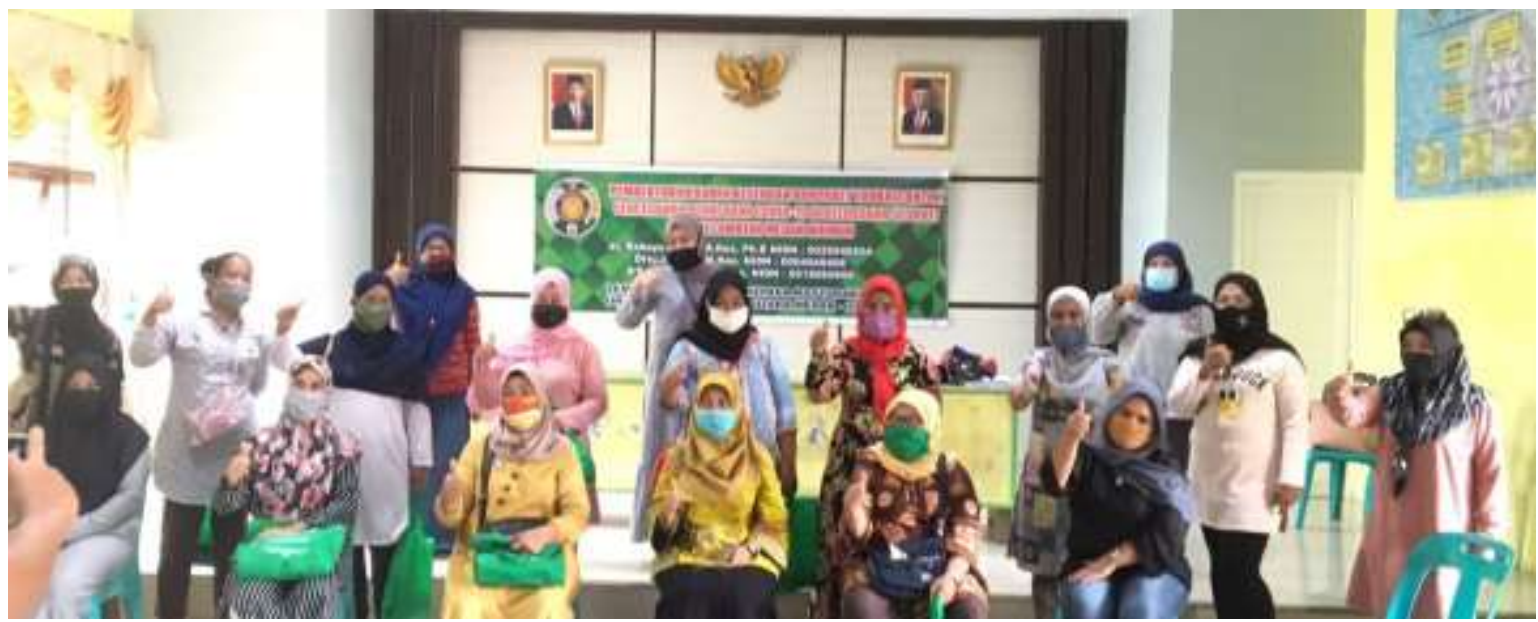

Gambar 3.2 Foto bersama peserta pengabdian dan pemateri

\section{KESIMPULAN}

Terdapat peningkatan pengetahuan peserta pengabdian pada masyarakat di kelurahan Sei Mati Kecamatan Medan Maimun sebelum dan sesudah intervensi penyuluhan tentang paket edukasi Covid-19 sebesar 14,7\%. Kurangnya pengetahuan peserta pengabdian sebelum intervensi dilakukan yaitu mengenai jarak tular virus corona bila seseorang yang terinfeksi Covid-19 batuk, lama pemakaian masker dan kapan harus ganti masker, cara mencuci tangan yang benar dan stigmatisasi pada penderita Covid-19. Setelah intervensi dilakukan terjadi peningkatan pengetahuan tentang Covid-19 dan upaya pencegahannya, walaupun masih ada yang pengetahuan tentang cara penularan Covid-19 dan manfaat minuman panas yang hasil jawabannya sama sebelum dan sesudah intervensi 


\section{UCAPAN TERIMAKASIH}

Artikel ini adalah hasil dari Program Pengabdian kepada Masyarakat yang dibiayai oleh Dana Non PNPB Universitas Sumatera Utara Sesuai dengan Surat Perjanjian Penugasan Pelaksanaan Program Pengabdian kepada Masyarakat Mono Tahun Dosen Muda Tahun Anggaran 2020 Nomor: 673/ UN5.2.3.2.1/ PPM /2020, Tanggal 29 Juli 2020. Ucapan terima kasih di tujukan kepada Rektor Universitas Sumatera Utara atas dukungan dana dan fasilitas yang diberikan, Lurah Sei Mati Kecamatan Medan Maimun yang telah mengizinkan lokasi pengabdian dan para kader yang berpartisipasi pada kegiatan pengabdian ini

\section{DAFTAR PUSTAKA}

Gorbalenya, A. E. et al. (2020) 'The species Severe acute respiratory syndrome-related coronavirus: classifying 2019-nCoV and naming it SARS-CoV-2', Nature Microbiology, 5(March). doi: 10.1038/s41564- 020-0695-z.

Satgas Covid-19 (2020). Tersedia di: https://covid19.go.id (Akses: 16 Desember 2020).

Posko Covid-19 provsu (2020). Tersedia di: https://covid19.sumutprov.go.id (Akses: 16 Desember 2020).

Posko Covid-19 Kota Medan (2020). Tersedia di: https://covid19.pemkomedan.go.id (Akses: 16 Desember 2020).

Lin, L. et all. (2020) 'Hypothesis for potential pathogenesis of SARS-CoV-2 infection--a review of immune changes in patients with viral pneumonia.', Emerging microbes \& infections. Taylor \& Francis. doi: 10.1080/22221751.2020.1746199.

Kemkes RI, 2020. Pedoman Pemberdayaan Masyarakat Dalam Pencegahan Covid-19 di RT/RW/Desa, Jakarta

Dirjend P2P Kemenkes RI, 2020. Pedoman Pencegahan dan pegendalian Corona virus disease (Covid-19) Revisi ke 4, Jakarta

Zhahrina, 2020. WHO umumkan wabah virus Corona berstatus darurat global, artinya?

Naufal Dzulfaroh, 2020. Update virus Corona di Indonesia Rincian kasus Covid-19 di 32 Propinsi

Rizma Adlia Syakurah \& Jesica Moudy, 2020. Pengetahuan terkait usaha pencegahan Corona virus disease (Covid-19) di Indonesia. HIGEIA (Journal of Public Health Research and Development), Vol 4(3), 333-346 